\title{
ERRATA TO THE PAPER
}

"Definability of classes of graphs in the first order predicate calculus with identity“

$$
\text { Studia Logica } 32 \text { (1973), pp. 159-188, }
$$

$$
\text { by } \mathbf{L} \text {. Koncewicz }
$$

On page 160 after line 13 from top add: "In the sections $3-5$ the term " $p$-layer graph" is used in a wider sense defined by the condition 1 of this definition". 
Zaklad Narodowy im. Ossoliniskich - Wydawnictwo. Wroclaw 1974. Naklad: 800 egz. Objętośc: ark. wyd, 8,60, ark. druk. 7,50, ark. A1 10. Papier ilustr. kl. III, $80 \mathrm{~g}, 70 \times 100$, Oddano do skladania 12 XI 1973. Poupisino do druku $15 \mathrm{~V}$ 1974. Druk ukoniczono w maju 1974. Wroclawska Drukarnia Naukowa. Zatm. 1374/73. Cena zł 45.- 